\title{
Gambaran karakteristik gagal jantung pada anak di RSUP Prof. Dr. R. D. Kandou Manado
}

\author{
${ }^{1}$ Agnes A. Anthonius \\ ${ }^{2}$ Erling D. Kaunang \\ ${ }^{2}$ Ari L. Runtunuwu
}

\author{
${ }^{1}$ Kandidat Skripsi Fakultas Kedokteran Universitas Sam Ratulangi Manadao \\ ${ }^{2}$ Bagian Ilmu Kesehatan anak Fakultas Kedokteran Universitas Sam Ratulangi Manado \\ Email: agnesangelia9@yahoo.com
}

\begin{abstract}
Heart failure is the inability of the heart to pump adequate blood that fulfils the metabolic demands of the body, including growth. In Indonesia, it is still difficult to find the prevalence and incidence of heart failure in children. This study was aimed to determine the characteristic features of heart failure in children at Prof. Dr. R. D. Kandou Hospital Manado. This was a retrospective descriptive study with a cross-sectional design. Data were obtained from the medical records of pediatric patients with heart failure within the period of January 2013 to August 2016 in the Child Health Department at Prof. Dr. R. D. Kandou Hospital. The results showed that there were 69 children with heart failure; the most common were females and age 12-18 years. The most common signs and symptoms were shortness of breath, fever, and cough. Heart murmurs and gallop were frequently found. Hepatomegaly, splenomegaly, ascites and edema of the legs were not commonly found. The electrocardiogram results were mostly sinus rhythm. The echocardiography results were mostly mitral regurgitation. The most common comorbid disease was rheumatic heart disease. Conclusion: At Prof. Dr. R. D. Kandou Hospital, heart failure in children was mostly found among females and age of 12-18 years. Most of the children showed shortness of breath, fever, and cough.
\end{abstract}

Keywords: heart failure, child, characteristic features

\begin{abstract}
Abstrak: Gagal jantung merupakan ketidakmampuan jantung sebagai pompa darah untuk memenuhi secara adekuat kebutuhan metabolisme tubuh termasuk pertumbuhan. Di Indonesia sendiri masih sulit menemukan data prevalensi dan insiden gagal jantung pada anak. Penelitian ini bertujuan mengetahui gambaran karakteristik gagal jantung pada anak di RSUP Prof. Dr. R. D. Kandou Manado. Jenis penelitian ialah deksriptif retrospektif dengan desain potong lintang. Data penelitian diambil dari rekam medik pasien anak dengan gagal jantung periode Januari 2013 sampai Agustus 2016 di Bagian Ilmu Kesehatan Anak RSUP Prof. Dr. R. D. Kandou Manado. Hasil penelitian mendapatkan 69 anak, terbanyak pada usia 12-18 tahun dan jenis kelamin perempuan. Tanda dan gejala terbanyak ialah sesak napas, demam, dan batuk. Bising jantung dan galop banyak ditemukan. Hepatomegali, splenomegali, ascites dan edema tungkai tidak banyak ditemukan. Hasil elektrokardiogram terbanyak ditemukan ialah irama sinus. Hasil ekokardiografi terbanyak ditemukan ialah regurgitasi mitral. Penyakit penyerta terbanyak ialah penyakit jantung rematik. Simpulan: Gagal jantung anak di RSUP Prof. Dr. R. D. Kandou Manado terbanyak pada usia 12-18 tahun, jenis kelamin perempuan, dengan gejala klinik sesak napas, demam, dan batuk.
\end{abstract}

Kata kunci: gagal jantung, anak, gambaran karakteristik

Gagal jantung merupakan masalah khusus pada anak berupa ketidakmampuan jantung sebagai pompa darah untuk memenuhi secara adekuat kebutuhan metabolisme tubuh termasuk pertumbuhan. ${ }^{1,2}$ Prevalensi dan insiden gagal jantung anak di dunia saat ini belum ditemukan data pasti, karena belum terdapat klasifikasi universal yang 
diterapkan terhadap gagal jantung anak. Gagal jantung anak terbanyak berasal dari anak yang lahir dengan malformasi kongenital. Diperkirakan bahwa 15\% sampai $25 \%$ anak-anak yang memiliki penyakit jantung struktural menjadi gagal jantung dikemudian hari. ${ }^{3}$

Dua studi dari gagal jantung pada anak masing-masing mencakup 10 tahun, telah dilaporkan dari fasilitas tersier Eropa. ${ }^{4,5}$ Lebih dari setengah kasus gagal jantung anak dilaporkan dalam kedua studi disebabkan oleh penyakit jantung bawaan. Hal ini mencerminkan fakta bahwa penyakit jantung bawaan jauh lebih umum daripada penyebab lain dari gagal jantung. Penyebab gagal jantung dominan yang dilaporkan diantara negara berkembang ialah kardiomiopati primer. Kejadian dari kardiomiopati primer di negara-negara berkembang dilaporkan antara 0,8 sampai 1,3 kasus per 100.000 anak di kelompok usai 0-18 tahun. ${ }^{6}$

Di Indonesia sendiri masih sulit menemukan data prevalensi dan insiden gagal jantung pada anak. Penelitian ini bertujuan untuk mengetahui gambaran karakteristik gagal jantung pada anak di RSUP Prof. Dr. R. D. Kandou Manado.

\section{METODE PENELITIAN}

Jenis penelitian ini ialah deksriptif retrospektif dengan desain potong lintang. Sampel penelitian ini ialah semua pasien anak gagal jantung yang dirawat di RSUP Prof. Dr. R. D. Kandou Manado periode Januari 2013-Agustus 2016 yang memiliki data rekam medik lengkap, yaitu data identitas pasien, keluhan, pemeriksaan fisik dan pemeriksaan penunjang.

\section{HASIL PENELITIAN}

Berdasarkan hasil penelitian yang dilakukan di Bagian Ilmu Kesehatan Anak RSUP Prof. Dr. R. D. Kandou Manado, dalam kurun waktu Januari 2013-Agustus 2016, terdapat 69 pasien dengan diagnosis gagal jantung yang memenuhi kriteria inklusi penelitian.

Tabel 1 memperlihatkan terbanyak anak berusia $12-18$ tahun $(52,2 \%)$.
Tabel 1. Distribusi gagal jantung anak berdasarkan usia

\begin{tabular}{ccc}
\hline Usia & $\mathbf{N}$ & $\mathbf{( \% )}$ \\
\hline 1 bulan- 1 tahun & 9 & 13 \\
$1-3$ tahun & 4 & 5,8 \\
4-6 tahun & 4 & 5,8 \\
$7-11$ tahun & 16 & 23,2 \\
$12-18$ tahun & 36 & 52,2 \\
Total & 69 & 100 \\
\hline
\end{tabular}

Pada Tabel 2 didapatkan terbanyak anak dengan jenis kelamin perempuan yang berjumlah 38 anak $(55,1 \%)$.

Tabel 2. Distribusi gagal jantung anak berdasarkan jenis kelamin

\begin{tabular}{lcc}
\hline \multicolumn{1}{c}{ Jenis kelamin } & N & $\mathbf{( \% )}$ \\
\hline Laki-laki & 31 & 44,9 \\
Perempuan & 38 & 55,1 \\
Total & 69 & 100 \\
\hline
\end{tabular}

Tabel 3 memperlihatkan tanda dan gejala terbanyak yang didapatkan berdasarkan keluhan ialah gejala sesak napas, yaitu sebanyak 56 anak $(81,2 \%)$.

Tabel 3. Distribusi gagal jantung anak berdasarkan tanda dan gejala

\begin{tabular}{lcc}
\hline Tanda dan gejala & $\mathbf{N}$ & $\mathbf{( \% )}$ \\
\hline Sesak napas & 56 & 81,2 \\
Demam & 38 & 55,1 \\
Batuk & 36 & 52,2 \\
Sianosis & 7 & 10,1 \\
Berkeringat & 5 & 7,2 \\
\hline
\end{tabular}

Tabel 4 memperlihatkan pada pemeriksaan mata didapatkan konjungtiva anemis pada 20 anak (29\%) dan sklera ikterik pada 6 anak $(6,7 \%)$.

Tabel 4. Distribusi gagal jantung anak berdasarkan pemeriksaan mata

\begin{tabular}{ccc}
\hline & $\mathbf{N}$ & $\mathbf{( \% )}$ \\
\hline Konjungtiva anemis & 20 & 29 \\
Sklera Ikterik & 6 & 8.7 \\
\hline
\end{tabular}

Tabel 5 memperlihatkan dari pemeriksaan dinding toraks didapatkan retraksi pada 24 anak $(34,8 \%)$. Pada pemeriksaan paru, ditemukan ronkhi pada 25 anak $(36,2 \%)$ dan wheezing pada 2 anak $(2,9 \%)$. 
Tabel 5. Distribusi gagal jantung anak berdasarkan pemeriksaan dinding toraks dan paru

\begin{tabular}{lcc}
\hline & N & $(\%)$ \\
\hline Retraksi & 24 & 34,8 \\
Ronkhi & 25 & 36,2 \\
Wheezing & 2 & 2,9 \\
\hline
\end{tabular}

Tabel 6 memperlihatkan dari pemeriksaan jantung didapatkan bising jantung pada 52 anak $(75,4 \%)$ dan galop pada 36 anak $(52,2 \%)$.

Tabel 6. Distribusi gagal jantung anak berdasarkan pemeriksaan jantung

\begin{tabular}{lll}
\hline & $\mathbf{N}$ & $\mathbf{( \% )}$ \\
\hline Bising jantung & 52 & 75,4 \\
Galop & 36 & 52,2 \\
\hline
\end{tabular}

Tabel 7 memperlihatkan dari pemeriksaan abdomen didapatkan hepatomegali pada 28 anak $(40,6 \%)$, splenomegali pada 5 anak (7,2\%), dan asites pada 12 anak $(17,4 \%)$. Pada pemeriksaan ektremitas didapatkan edema tungkai pada 21 anak $(30,4 \%)$.

Tabel 7. Distribusi karakteristik berdasarkan pemeriksaan abdomen dan ekstremitas

\begin{tabular}{lcl}
\hline & $\mathbf{N}$ & $\mathbf{( \% )}$ \\
\hline Hepatomegali & 28 & 40,6 \\
Splenomegali & 5 & 7,2 \\
Ascites & 12 & 17,4 \\
Edema tungkai & 21 & 30,4 \\
\hline
\end{tabular}

Tabel 8 memperlihatkan dari 69 anak didapatkan hasil pemeriksaan EKG pada 14 anak dengan hasil terbanyak ialah irama sinus pada 4 anak $(28,6 \%)$ dan sinus takikardi pada 3 anak $(21,4 \%)$.

Tabel 9 memperlihatkan dari 69 anak didapatkan hasil pemeriksaan ekokardiografi pada 35 anak dengan hasil terbanyak ialah regurgitasi trikuspid sebanyak 15 anak $(42,9 \%)$.

Berdasarkan Tabel 10, hasil pemeriksaan darah lengkap dari 63 anak yang melakukan pemeriksaan darah didapatkan kadar hematokrit menurun pada 41 anak (65\%). Dari 61 anak didapatkan kadar eritrosit menurun pada 42 anak
(68,8\%). Dari 64 anak didapatkan kadar hemoglobin menurun pada 42 anak (65,6\%), kadar leukosit meningkat pada 43 anak $(67,2 \%)$ dan kadar trombosit normal pada 44 anak $(68,8 \%)$.

Tabel 8. Distribusi gagal jantung anak berdasarkan pemeriksaan elektrokardiografi

\begin{tabular}{lcc}
\hline Simpulan EKG & N & $\mathbf{( \% )}$ \\
\hline Irama sinus normal & 4 & 28,6 \\
Sinus takikardi & 3 & 21,4 \\
Asystole & 1 & 7,1 \\
PVC Bigeminy & 1 & 7,1 \\
RBBB incomplete & 1 & 7,1 \\
RBBB complete & 1 & 7,1 \\
LAE (left atrium enlargement) & 3 & 21,4 \\
RAD (right axis deviation) & 1 & 7,1 \\
LPHB (left posterior & 1 & 7,1 \\
hemiblock) & 1 & 7,1 \\
Hipertrofi ventrikel kiri (LV) & 1 & 7,1 \\
Kardiomegali & 4 & 28,6 \\
Irama sinus normal & &
\end{tabular}

Tabel 9. Distribusi gagal jantung anak berdasarkan pemeriksaan ekokardiografi

\begin{tabular}{lcc}
\hline Simpulan ekokardiografi & N & $(\%)$ \\
\hline ASD & 4 & 11,4 \\
VSD & 3 & 8,6 \\
PDA & 3 & 8,6 \\
TOF & 1 & 2,9 \\
Dilatasi atrium kiri & 7 & 20 \\
Dilatasi atrium kanan & 1 & 2,9 \\
Dilatasi ventrikel kiri & 6 & 17,1 \\
Hipertrofi ventrikel kiri & 3 & 8,6 \\
Kardiomiopati dilatasi & 5 & 14,3 \\
Efusi perikardial & 4 & 11,4 \\
Efusi pleura & 2 & 5,7 \\
Pulmonary Hypertension & 7 & 20 \\
Trikuspid regurgitasi (TR) & 18 & 51,4 \\
Mitral regurgitasi (MR) & 19 & 54,3 \\
Aorta regurgitasi (AR) & 14 & 40 \\
Pulmonal regurgitasi (PR) & 16 & 45,7 \\
Mitral stenosis (MS) & 2 & 5,7 \\
Trikuspid stenosis (TS) & 1 & 2,9 \\
Prolaps katup mitral & 1 & 2,9 \\
Intrakardiak normal & 2 & 5,7 \\
\hline
\end{tabular}

Tabel 11 memperlihatkan hasil pemeriksaan enzim hati kadar SGOT normal pada 29 anak $(52,7 \%)$ dan meningkat pada 26 anak (47,3\%) sedangkan kadar SGPT normal pada 36 anak $(65,5 \%)$ dan meningkat pada 19 anak $(34,5 \%)$. 
Tabel 10. Distribusi gagal jantung anak berdasarkan pemeriksaan darah lengkap

\begin{tabular}{llc}
\hline & $\mathrm{N}$ & $(\%)$ \\
\hline Ht (\%) & $\mathrm{n}=63$ & \\
Menurun & 41 & 65 \\
Normal & 19 & 30.2 \\
Meningkat & 3 & 4.8 \\
Hb $(\mathbf{g} / \mathbf{d L})$ & $\mathrm{n}=64$ & \\
Rendah & 42 & 65.6 \\
Normal & 20 & 31.3 \\
Tinggi & 2 & 3.1 \\
Eritrosit $(\mathbf{1 0} / \boldsymbol{\mu L})$ & $\mathrm{n}=61$ & \\
Menurun & 42 & 68.8 \\
Normal & 15 & 24.6 \\
Meningkat & 4 & 6.6 \\
Leukosit $(/ \boldsymbol{\mu L})$ & $\mathrm{n}=64$ & \\
Menurun & 3 & 4.7 \\
Normal & 18 & 28.1 \\
Meningkat & 43 & 67.2 \\
Trombosit $(\mathbf{1 0} / \boldsymbol{\mu L})$ & $\mathrm{n}=64$ & \\
Menurun & 10 & 15.6 \\
Normal & 44 & 68.8 \\
Meningkat & 10 & 15.6 \\
\hline
\end{tabular}

Tabel 11. Distribusi karakteristik berdasarkan pemeriksaan enzim hati

\begin{tabular}{lll}
\hline & N & $\mathbf{( \% )}$ \\
\hline SGOT (U/L) & & \\
$\quad$ Normal $(<33)$ & 29 & 52.7 \\
Meningkat $(\geq 33)$ & 26 & 47.3 \\
SGPT (U/L) & & \\
$\quad$ Normal $(<43)$ & 36 & 65.5 \\
Meningkat $(\geq 43)$ & 19 & 34.5 \\
Total & 55 & 100 \\
\hline
\end{tabular}

Tabel 12 memperlihatkan terbanyak kadar ureum normal pada 37 anak $(63,8 \%)$ dan kadar kreatinin normal pada 40 anak $(69 \%)$.

Tabel 12. Distribusi gagal jantung anak berdasarkan pemeriksaan ureum dan kreatinin

\begin{tabular}{ccc}
\hline & $\mathbf{N}$ & $\mathbf{( \% )}$ \\
\hline Ureum $(\mathbf{m g} / \mathbf{d L})$ & & \\
Menurun $(<10)$ & 3 & 5.2 \\
Normal $(10-40)$ & 37 & 63.8 \\
Meningkat $(>40)$ & 18 & 31 \\
Kreatinin (mg/dL) & & \\
Menurun $(<0.5)$ & 13 & 22.4 \\
Normal $(0.5-1.5)$ & 40 & 69 \\
Meningkat $(>1.5)$ & 5 & 8.6 \\
Total & 58 & 100 \\
\hline
\end{tabular}

Tabel 13 memperlihatkan hasil pemeriksaan elektrolit dari 63 anak. Kadar natrium menurun pada 34 anak (54\%) dan normal pada 29 anak (46\%). Dari 63 anak, didapatkan terbanyak kadar kalium normal pada 38 anak (60,3\%). Dari 61 anak, didapatkan terbanyak kadar klorida menurun pada 26 anak $(42,6 \%)$, normal pada 33 anak (54,2\%). Dari 39 anak, didapatkan terbanyak kadar kalsium normal pada 25 anak $(64,1 \%)$.

Tabel 13. Distribusi gagal jantung anak berdasarkan pemeriksaan elektrolit

\begin{tabular}{ccc}
\hline & $\mathbf{N}$ & $\mathbf{( \% )}$ \\
\hline Natrium $(\mathbf{m E q} / \mathbf{L})$ & $\mathrm{n}=63$ & \\
Menurun $(<135)$ & 34 & 54 \\
Normal $(135-153)$ & 29 & 46 \\
Meningkat $(>153)$ & - & - \\
Kalium $(\mathbf{m E q} / \mathbf{L})$ & $\mathrm{n}=63$ & \\
Menurun $(<3.50)$ & 22 & 34.9 \\
Normal $(3.50-5.30)$ & 38 & 60.3 \\
Meningkat $(>5.30)$ & 3 & 4.8 \\
Klorida $(\mathbf{m E q} \mathbf{L})$ & $\mathrm{n}=61$ & \\
Menurun $(<98.0)$ & 26 & 42.6 \\
Normal $(98.0-109.0)$ & 33 & 54.1 \\
Meningkat $(>109.0)$ & 2 & 3.3 \\
Kalsium $(\mathbf{m g} / \mathbf{d L})$ & $\mathrm{n}=39$ & \\
Menurun $(<8.10)$ & 14 & 35.9 \\
Normal $(8.10-10.40)$ & 25 & 64.1 \\
Meningkat $(>10.40)$ & - & - \\
\hline
\end{tabular}

Tabel 14 memperlihatkan penyakit penyerta terbanyak ditemukan ialah penyakit jantung rematik sebanyak 25 anak $(36,2 \%)$, diikuti penyakit jantung bawaan (ASD, VSD, PDA, TOF) sebanyak 18 anak (26\%), pneumonia dan bronkopneumonia sebanyak 16 anak $(23,2 \%)$, syok kardiogenik dan gizi buruk/ gizi kurang sebanyak 13 anak (18,8\%) dan anemia sebanyak 10 anak (14,5\%). Tuberkulosis, ISK, dan sepsis/syok septik ditemukan pada 5 pasien $(7,2 \%)$.

\section{BAHASAN}

Data penelitian mendapatkan 69 anak dengan gagal jantung dari rekam medik periode Januari 2013 sampai Agustus 2016 di Bagian Ilmu Kesehatan Anak RSUP Prof. Dr. R. D. Kandou Manado. 
Tabel 14. Distribusi gagal jantung anak berdasarkan penyakit penyerta

\begin{tabular}{llc}
\hline Penyakit Penyerta & N & $\mathbf{( \% )}$ \\
\hline SOL & 1 & 1,4 \\
Serebral palsi & 1 & 1,4 \\
Tonsilofaringitis & 1 & 1,4 \\
Jantung dan Pembuluh darah & & \\
$\quad$ ASD & 5 & 7,2 \\
$\quad$ VSD & 6 & 8,7 \\
$\quad$ PDA & 5 & 7,2 \\
$\quad$ TOF & 2 & 2,9 \\
$\quad$ Hipertensi & 3 & 4,3 \\
$\quad$ Syok kardiogenik & 13 & 18,8 \\
$\quad$ Penyakit jantung rematik & 25 & 36,2 \\
$\quad$ Endokarditis & 1 & 1,4 \\
$\quad$ Kardiomiopati dilatasi & 3 & 4,3 \\
$\quad$ VHD & 8 & 11,6 \\
$\quad$ Efusi perikardium & 2 & 2,9 \\
Paru & & \\
$\quad$ Pneumonia / BP & 16 & 23,2 \\
$\quad$ Tuberkulosis & 5 & 7,2 \\
$\quad$ Edema paru & 2 & 2,9 \\
$\quad$ Efusi pleura & 4 & 5,8 \\
Gastritis & 1 & 1,4 \\
GNA (Glomerulonefritis akut) & 1 & 1,4 \\
Gangguan ginjal kronik & 2 & 2,9 \\
ISK (Infeksi saluran kemih) & 5 & 7,2 \\
Pedikulosis kapitis & 1 & 1,4 \\
Skabies & 1 & 1,4 \\
Gizi buruk/ gizi kurang & 13 & 18,8 \\
Anemia & 10 & 14,5 \\
SLE & 1 & 1,4 \\
Sepsis / syok septik & 5 & 7,2 \\
\hline
\end{tabular}

Karakteristik terbanyak anak dengan usia 12-18 tahun yang berjumlah 36 anak $(52,2 \%)$, diikuti usia 7-11 tahun sebanyak 16 anak $(23,2 \%)$, dan usia 1 bulan- $<1$ tahun sebanyak 9 anak (13\%). Hasil serupa juga dilaporkan di Medan, dari 25 sampel, rerata umur sampel adalah 10 tahun 4 bulan dengan termuda berusia 1 bulan dan tertua berusia 18 tahun. $^{7}$ Hal ini sesuai dengan acuan pustaka bahwa gagal jantung pada anak terbanyak terjadi dibawah usia 1 tahun dengan kelainan struktur jantung, dan usia 5-15 tahun dengan penyebab penyakit jantung rematik. ${ }^{8,9}$

Jenis kelamin terbanyak didapatkan perempuan $(55,1 \%)$ dibandingkan anak dengan jenis kelamin laki-laki (44,9\%). Penelitian lain di RSUP H. Adam Malik Medan tahun 2007-2009 juga didapatkan anak perempuan dengan gagal jantung $(52 \%)$ lebih banyak dibandingkan anak laki-laki (48\%). ${ }^{7}$

Tanda dan gejala terbanyak yang didapatkan berdasarkan keluhan ialah gejala sesak napas $(81,2 \%)$, diikuti dengan keluhan demam $(55,1 \%)$, batuk $(52,5 \%)$, sianosis $(10,1 \%)$, dan berkeringat $(7,2 \%)$. Hal ini serupa dengan AHA yang mengatakan bahwa anak dengan gagal jantung akan didapatkan terbanyak kesulitan bernapas dan demam sesuai dengan penyebabnya, yakni pada anak besar adalah demam rematik. ${ }^{10,11}$ Pada anak besar sesak napas seringkali dikeluhkan dengan cepat lelah, tidak tahan kerja fisik, dan batuk. Sianosis dan berkeringat dapat ada tetapi tidak umum. ${ }^{1}$

Dari pemeriksaan mata, didapatkan konjungtiva anemis (29\%) dan sklera ikterik $(6,7 \%)$. Hal ini disebabkan karena pada beberapa anak didapatkan anemia. Gagal jantung dapat merupakan komplikasi akibat anemia. $^{9,12}$ Penelitian lain di Gambia, Afrika, dilaporkan bahwa pada pasien yang anemia berat, terjadi gagal jantung yang juga terdapat kongjungtiva pucat. ${ }^{13}$ Sklera ikterik hanya didapatkan pada sebagian kecil pasien, dapat disebabkan karena adanya gangguan hepar. ${ }^{1}$

Dari pemeriksaan dinding toraks, didapatkan retraksi pada 24 anak $(34,8 \%)$. Pada pemeriksaan paru, ditemukan ronkhi (36,2\%) dan wheezing (2.9\%). Daphne dan Gail $^{14}$ mengatakan hal serupa bahwa retraksi sebagai salah satu temuan khas gagal jantung pada anak, tetapi menurut klasifikasi Ross ${ }^{14,15}$ retraksi didapatkan pada anak gagal jantung kelas IV. Radford et $\mathrm{al}^{16}$ menemukan pada pemeriksaan fisik auskultasi pasien gagal jantung sebagian besar didapatkan ronkhi. Dari penelitian ini retraksi dan rhonki didapatkan pada sebagian kecil pasien, tidak mencapai setengah dari jumlah anak gagal jantung. Hal ini dapat ditemukan pada anak dengan gagal jantung ${ }^{1}$ sedangkan wheezing bukan tanda khas gagal jantung.

Dari pemeriksaan jantung, didapatkan bising jantung $(75,4 \%)$ dan galop $(52,2 \%)$. 
Radford et al ${ }^{16}$ menemukan bising jantung (murmur) sering pada pasien gagal jantung, intensitas biasanya digolongkan menjadi grade 1-6 untuk murmur sistolik dan grade 1-4 untuk murmur diastolik. Irama galop seringkali terdengar tetapi untuk bising jantung yang dihasilkan sesuai dengan lesi jantung yang mendasari. ${ }^{1}$

Pada pemeriksaan abdomen, didapatkan hepatomegali $(40,6 \%)$, splenomegali $(7,2 \%)$, dan ascites $(17,4 \%)$. Pada pemeriksaan ekstremitas didapatkan edema tungkai $(30,4 \%)$. Hal ini sesuai dengan penelitian dan kepustakaan sebelumnya bahwa hepatomegali merupakan tanda yang sering terjadi pada gagal jantung. ${ }^{1,2,9,15,16}$ Splenomegali tidak umum terjadi, tetapi dapat diakibatkan karena adanya gangguan sirkulasi yang menyebabkan kongesti pembuluh darah di limpa dan terjadi pembesaran limpa. Asites dan edema tungkai juga merupakan gejala khas gagal jantung dan dapat ada. 1,12,15,16

Hasil pemeriksaan elektrokardiografi dari 14 anak, didapatkan terbanyak ialah irama sinus normal $(28,6 \%)$ dan irama sinus takikardi $(21,4 \%)$. Dari penelitian yang dilakukan di Bandung, temuan terbanyak ialah sinus takikardi pada 27 anak dan irama sinus normal pada 5 anak. ${ }^{17}$ Sinus takikardi dapat dijumpai pada gagal jantung. ${ }^{18}$

Hasil pemeriksaan ekokardiografi dari 35 anak didapatkan terbanyak ialah regurgitasi mitral (54,3\%), diikuti regurgitasi trikuspid $(51,4 \%)$, regurgitasi pulmonal $(45,7 \%)$, regurgitasi aorta $(40 \%)$, dilatasi atrium kiri dan hipertensi pulmonal (20\%), dilatasi ventrikel kiri $(17,1 \%)$, ASD dan efusi perikardium $(11,4 \%)$, dan PDA, VSD, dan hipertrofi ventrikel kiri $(8,6 \%)$. Harbanu dan Anwar ${ }^{19}$ menyatakan terbanyak didapatkan ialah regurgitasi mitral karena salah satu penyebab utama terjadinya gagal jantung ilah regurgitasi mitral. Regusitasi mitral dan regurgitasi aorta menyebabkan kelebihan beban volume (peningkatan preload). ${ }^{19}$ Penelitian lainnya didapatkan hasil terendah pada ASD. ${ }^{7}$ Pada gagal jantung umumnya juga memberi gambaran dilatasi katup.
Berdasarkan hasil pemeriksaan darah lengkap, dari 63 anak yang melakukan pemeriksaan darah didapatkan kadar hematokrit menurun pada 41 anak $(65 \%)$. Dari 64 anak didapatkan kadar hemoglobin menurun pada 42 anak $(65,6 \%)$ dan normal pada 20 anak (31,3\%). Dari 61 anak didapatkan kadar eritrosit menurun pada 42 anak $(68,8 \%)$ dan normal pada 15 anak $(24,6 \%)$. Dari 64 anak didapatkan kadar leukosit terbanyak meningkat pada 43 anak $(67,2 \%)$ dan normal pada 18 anak $(28,1 \%)$. Dari 64 anak didapatkan kadar trombosit terbanyak normal pada 44 anak $(68,8 \%)$, Penelitian dengan hasil serupa dilaporkan di RSUP Haji Adam Malik Medan tahun 2011-2012. ${ }^{20}$ Penelitian lain juga melaporkan kadar $\mathrm{Hb}$ yang rendah ditemukan pada pasien gagal jantung sebanyak $33,6 \%$. $^{21}$ Kadar hematokrit dan eritrosit yang menurun bisa disebabkan karena anemia, malnutrisi dan gagal ginjal. Ditemukan keadaan anemia pada beberapa anak ditunjang dengan hasil pemeriksaan darah terjadi penurunan kadar hemoglobin yang dominan dibandingkan yang dengan hemoglobin normal. Leukosit yang meningkat menandakan adanya infeksi. ${ }^{13}$

Hasil pemeriksaan enzim hati dari 55 anak yang melakukan pemeriksaan, didapatkan kadar SGOT normal pada 29 anak $(52,7 \%)$ dan meningkat pada 26 anak $(47,3 \%)$ sedangkan kadar SGPT normal pada 36 anak $(65,5 \%)$ dan meningkat pada 19 anak (34,5\%). Peningkatan kadar SGOT dan SGPT juga dilaporkan pada penelitian lain, dan simpulkan terdapat hubungan antara gagal jantung dan gangguan fungsi hati walau secara statistik tidak bermakna. ${ }^{22}$ Kadar SGOT dan SGPT yang meningkat 3-5 kali dari nilai normal dapat menandakan gagal jantung. ${ }^{23}$

Berdasarkan hasil pemeriksaan ureum dan kreatinin, dari 58 anak yang melakukan pemeriksaan, didapatkan kadar ureum yang normal pada 37 anak $(63,8 \%)$ dan meningkat pada 18 anak (31\%) sedangkan kadar kreatinin menurun pada 13 anak $(22,4 \%)$, normal pada 40 anak $(69 \%)$ dan meningkat pada 5 anak $(8,6 \%)$. Penelitian lain juga melaporkan peningkatan ureum 
dan kreatinin pada gagal jantung berat dan memiliki kesimpulan bahwa ureum dan kreatinin dapat menjadi salah satu prediktor mortalitas. ${ }^{24-26}$

Berdasarkan hasil pemeriksaan elektrolit, dari 63 anak didapatkan kadar natrium menurun pada 34 anak (54\%) dan normal pada 29 anak (46\%). Dari 63 anak, didapatkan kadar kalium menurun pada 22 anak $(34,9 \%)$ dan normal pada 38 anak $(60,3 \%)$. Dari 61 anak, didapatkan kadar klorida menurun pada 26 anak $(42,6 \%)$ dan normal pada 33 anak (54,2\%). Dari 39 anak, didapatkan kadar kalsium menurun pada 14 anak $(35,9 \%)$ dan normal pada 25 anak $(64,1 \%)$. Penelitian serupa melaporkan pada pemeriksaan elektrolit, terbanyak ditemukan kadar natrium dan kalium yang menurun. Dilaporkan juga pada pasien dengan penurunan kadar natrium dan kalium ditemukan prognosis yang lebih buruk tetapi hal ini bukan menjadi faktor independen untuk menentukan prognosis. ${ }^{27}$ Didukung oleh kepustakaan sebelumnya bahwa kadar natrium yang rendah, serta ureum dan kreatinin yang meningkat memberikan prognosis buruk pada gagal jantung. ${ }^{12}$

Penyakit penyerta terbanyak ditemukan pada anak dengan gagal jantung adalah penyakit jantung rematik sebanyak 25 anak, diikuti penyakit jantung bawaan sebanyak 18 anak, pneumonia dan bronkopneumonia sebanyak 16 anak, syok kardiogenik dan gizi buruk/ gizi kurang sebanyak 13 anak dan anemia sebanyak 10 anak. Hal ini sesuai dengan penelitian di RSUP H. Adam Malik Medan dan kepustakaan bahwa pada anak lebih besar, penyebab gagal jantung seringkali didapat akibat demam rematik. ${ }^{1,7,14}$ Penyakit jantung bawaan pada anak sering berkomplikasi menjadi gagal jantung dan pneumonia dapat terjadi sekunder akibat kongesti paru. ${ }^{9,28}$ Syok kardiogenik juga merupakan salah satu komplikasi terbanyak yang terjadi akibat gagal jantung. ${ }^{1,14}$ Paul et al. ${ }^{15}$ menyatakan gejala kelas III pada gagal jantung anak adalah gagal tumbuh termasuk gizi buruk/ gizi kurang digambarkan dengan kesulitan makan pada anak. Penelitian lain juga menemukan anemia ringan pada pasien gagal jantung sebesar 57\%, dan memiliki kesimpulan anemia sering ditemukan pada gagal jantung. ${ }^{21}$

\section{SIMPULAN}

Gagal jantung anak ditemukan terbanyak pada usia 12-18 tahun dan jenis kelamin perempuan. Tanda dan gejala gagal jantung anak ditemukan terbanyak ialah sesak napas, demam, dan batuk. Bising jantung dan galop banyak ditemukan pada gagal jantung anak.

Hasil elektrokardiografi terbanyak ditemukan ialah irama sinus sednagkan hasil ekokardiografi terbanyak ialah regurgitasi mitral. Penyakit penyerta pada anak dengan gagal jantung terbanyak ialah penyakit jantung rematik.

\section{SARAN}

Perlu dilakukan penyuluhan kepada masyarakat mengenai penyakit jantung rematik yang menyebabkan gagal jantung pada anak remaja. Perlu dilakukan penelitian lebih lanjut mengenai faktorfaktor risiko penyebab gagal jantung pada anak

\section{DAFTAR PUSTAKA}

1. Behrman RE, Kliegman RM, Arvin AM. Textbook of Pediatrics (17th ed). Philadelphia: Saunders (an imprint of Elsevier Science), 2003; p.1583.

2. Erin M, Silberbach M. Heart failure in infants and children. Pediatrics in Review. 2010;31;4.

3. Boucek MM, Edwards LB, Keck BM, Trulock EP, Taylor DO, Hertz MI. Registry for the International Society for Heart and Lung Transplantation: seventh official pediatric report. $\mathrm{J}$ Heart Lung Transplant. 2004;23:93347.

4. Sommers C, Nagel BH, Neudorf U, Schmaltz AA. Congestive heart failure in childhood. An epidemiologic study. Herz. 2005;30:652-62.

5. Massin MM, Astadicko I, Dessy H. Epidemiology of heart failure in a 
tertiary pediatric center. Clin Cardiol. 2008;31:388 -91.

6. Andrews RE, Fenton MJ, Ridout DA, Burch M. New-onset heart failure due to heart muscle disease in childhood: a prospective study in the United Kingdom and Ireland. Circulation. 2008;117:79-84.

7. Akhmad F. Karakteristik penderita gagal jantung pada anak yang dirawat di RSUP H. Adam Malik Medan tahun 2007-2009. [cited 14 November 2016]. Available from: http://repository.usu.ac.id/handle/123 456789/22715

8. Supriyatno, Bambang. Management of Pediatric Heart Disease for Practitioner: From Early Detection to Intervention. Jakarta: Departemen IKA FKUI-RSCM, 2009.

9. Indonesia Heart Association. Gagal jantung. [cited 10 November 2016]. Available from:

http://www.inaheart.org/upload/file/P edoman_TataLaksana_Gagal_Jantung 2015.pdf

10. Rahayuningsih SE, Farrah A. Role of echocardiography in diagnose of acute rheumatic fever. Paediatrica Indonesiana. 2010;50:2.

11. American Heart Association. Heart Failure in Children and Adolescents. [cited 10 November 2016]. Available from: http://www.heart.org/HEARTORG/C onditions/HeartFailure/AboutHeartFa ilure/Heart-Failure-in-Children-andAdolescents_UCM_311919_Article.j sp\#.WCRZJdxpk7Q

12. Daulat M, Muhadi. Gagal jantung akut. In: Siti S, Idrus A, Aru W, Marcellus S, Bambang S, Ari F, editors. Buku Ajar Ilmu Penyakit Dalam (6th ed). Jakarta Pusat: Interna Publishing, 2014;p. 1136-41.

13. Weber M, Kellingray S, Palmer A, Jaffar S, Mulholland EK, Greenwood BM. Pallor as a clinical sign of severe anaemia in children: an investigation in the Gambia. WHO Bulletin OMS. 2007;75:113-8.

14. Hsu DT, Pearson GD. Heart failure in children Part I: History, etiology, and pathophysiology. Circ Heart Fail. 2009;2:63-70.

15. Kantor PF, Lougheed J, Dancea A,
McGillion M, Barbosa N, Chan C, et al. Presentation, Diagnosis, and Medical Management of Heart Failure in Children: Canadian Cardiovascular Society Guidelines. Can J Cardiol. 2013;29:1535-52.

16. Radford MJ, Arnold MO, Bennet SJ, Cinquegrani MP, Cleland JG, Havranek EP, et al. ACC/AHA Heart Failure Clinical Data Standards. 14 September 2005. [cited 14 November 2016]. Available from: http://circ.ahajournals.org/content/ear 1y/2005/09/14/CIRCULATIONAHA. 105.170073.short

17. Sri ER. Manifestasi klinis dan fungsi ventrikel pada kardiomiopati dilatasi. Sari Pediatri. 2015;16:403-8.

18. Malcolm S. Satu-satunya Buku EKG yang Anda Perlukan (7th ed). Jakarta: EGC, 2013; p.109.

19. Harbanu HM, Anwar S. Gagal jantung. J Int Med. 2008;8:85-94.

20. Lazuardi MF. Gambaran hematologi pada penderita gagal jantung yang dirawat di bangsal Penyakit Dalam di RSUP Haji Adam Malik Medan pada tahun 2011 Sampai 2012. 13 Maret 2014. [cited 14 November 2016]. Available from:

http://repository.usu.ac.id/handle/123 456789/39997

21. Aaron C. Prevalensi anemia pada pasien gagal jantung di RSUP Prof. Dr. R. D. Kandou Manado periode 2013. [cited 14 November 2016]. Available from:

http://ejournal.unsrat.ac.id/index.php/ eclinic/article/view/6748

22. Masola AB, Panda AL, Kawengian V. Hubungan gagal jantung dan fungsi hati. eCl. 2016;4:2.

23. Indah AD. Hubungan peningkatan SGPT dengan hasil HBsAg pada pasien hepatitis B di Rumah Sakit Marsudi Waluto pada tahun 2011. [cited tanggal 10 November 2016]. Available from: http://jurnalhealthyscience.com/wpcontent/uploads/2016/05/02-042012agustina.pdf

24. Schrier RW. Blood urea nitrogen and serum creatinine: not married in heart failure. Circ Heart Fail. 2008;1:2-5.

25. Hillege HL, Girbes AR, Kam PJ, 
Boomsma F, Charlesworth A, Zeeuw DD, et al. Renal function, neurohormonal activation, and survival in patients with chronic heart failure. Circulation. 2000;102:203-10.

26. Dorron A, Murray A, Andrew J. Elevated blood urea nitrogen level as a predictor of mortality in patients admitted for decompensated heart failure. Am J Med. 2004;116:466-73.

27. Dargie HJ, Cleland JG, Leckie BJ, Inglis CG, East BW, Ford I. Relation of arrhythmias and electrolyte abnormalities to survival in patients with severe chronic heart failure. [cited 14 November 2016]. Available from:

http://europepmc.org/abstract/med/30 32475

28. Didik H. Profil penyakit jantung bawaan di Instalasi Rawat Inap Anak RSUP Dr. M. Djamil Padang Januari 2008Februari 2011. Sari Pediatri. 2012;14:152-7. 